Available online on 15.09.2018 at http://jddtonline.info

Journal of Drug Delivery and Therapeutics

Open Access to Pharmaceutical and Medical Research

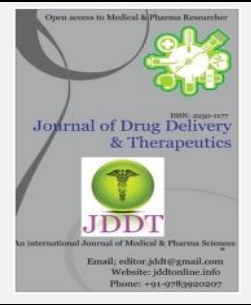

Open $\bigcirc$ Access

Research Article

\title{
RP-HPLC METHOD DEVELOPMENT AND VALIDATION FOR SIMULTANEOUS ESTIMATION OF ASPIRIN AND OMEPRAZOLE IN BULK AND DOSAGE FORM
}

\author{
Sarode Tukaram K ${ }^{1 *}$, Jadhav Prerana $B^{2 *}$ \\ ${ }^{1}$ Department of Quality Assurance Technique, SND College of Pharmacy, Babhulgaon, Yeola, Nashik- 423401, Maharashtra, India \\ ${ }^{2}$ Jadhav Prerana Bhaskar, Dept. of Pharmaceutical Chemistry, SND College of Pharmcy, Yeola, Nashik-423401, Maharashtra, India
}

\begin{abstract}
RP-HPLC method was developed for the determination of Omeprazole (OME) \& Aspirin (ASP) in bulk and dosage form. Mobile phase use for the separation of OME \& ASP is methanol and 0.05\% OPA in water $(\mathrm{pH}=3.5)$ with ratio of 60:40. The Colum used as $\mathrm{C}_{18}$ (Cosmosil) $4.6 \times 150 \mathrm{~mm}$ and flow rate $0.7 \mathrm{~mL} / \mathrm{min}$. UV detector is used and the detection wavelength is $231 \mathrm{~nm}$. Retention time of $\mathrm{OME}$ and ASP are $4.61 \& 8.03 \mathrm{~min}$, respectively. This method was validated as per ICH guidelines. Linearity was observed at $10-$ $50 \mu \mathrm{g} / \mathrm{mL}$ of OME and $20-100 \mu \mathrm{g} / \mathrm{mL}$ of ASP. The \% RSD is found to be less than $2 \%$. The resolution between OME and ASP is 11.55 and the tailing factors of both are less than 2.0.Therotical plates for OME and ASP are 5060, and 9367, respectively. Total run time is $15 \mathrm{~min}$. The developed RP-HPLC method was accurate, precise, selective and rapid for simultaneous estimation of Omeprazole and Aspirin in the pharmaceutical dosage form."
\end{abstract}

Keyword: Omeprazole, Aspirin, RP-HPLC validation.

Article Info: Received 23 June, 2018; Review Completed 10 Aug 2018; Accepted 24 Aug 2018; Available online 15 Sep 2018

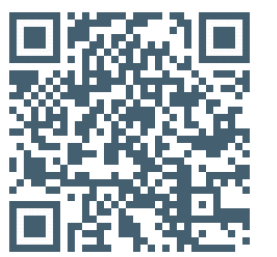

\section{Cite this article as:}

Sarode TK, Jadhav PB, RP-HPLC method development and validation for simultaneous estimation of aspirin and omeprazole in bulk and dosage form, Journal of Drug Delivery and Therapeutics. 2018; 8(5):322-328 DOI: http://dx.doi.org/10.22270/jddt.v8i5.1825

\section{*Address for Correspondence:}

Sarode Tukaram K, Department of Quality Assurance Technique, SND College of Pharmacy, Babhulgaon, Yeola, Nashik- 423401, Maharashtra, India

\section{INTRODUCTION}

YOSPRALA is a combination of aspirin, an anti-platelet agent, and omeprazole, a proton pump inhibitor (PPI), indicated for patients who require aspirin for secondary prevention of cardiovascular and cerebrovascular events and who are at risk of developing aspirin associated gastric ulcers.

Reducing the combined risk of death and nonfatal stroke in patients who have had ischemic stroke or transient ischemia of the brain due to fibrin platelet emboli,

- Reducing the combined risk of death and nonfatal MI in patients with a previous MI or unstable angina pectoris,
- Reducing the combined risk of MI and sudden death in patients with chronic stable angina pectoris,

- Use in patients who have undergone revascularization procedures (Coronary Artery Bypass Graft [CABG] or Percutaneous Transluminal Coronary Angioplasty [PTCA]) when there is a pre-existing condition for which aspirin is already indicated.

The omeprazole component of YOSPRALA is indicated for decreasing the risk of developing aspirin associated gastric ulcers in patients at risk for developing aspirinassociated gastric ulcers due to age $(\geq 55)$ or documented history of gastric ulcers.

The aim of the present work was to develop simple, economic, accurate, specific and precise RP-HPLC 
methods for simultaneous estimation of omeprazole and aspirin in bulk drugs and combined pharmaceutical formulation and validation of newly developed analytical method.

Omeprazole is use proton pump inhibitor (Antacid), chemically (4-methoxy-3,5-dimethylpyridyl,5methoxybbenzimidazol.Litreature survey of omeprazole has been estimated by UV, HPLC, HPTLC, RP-HPLC.<smiles>COc1ccc2nc(S(=O)Cc3ncc(C)c(OC)c3C)[nH]c2c1</smiles>

Figure 1: Omeprazole

Aspirin is use as antithrombotic, antianginal, antipyretic and anti-inflammatory agent chemically (2Acetoxybenzoic acid) aspirin is a use to lower risk to heart attack, artery disease $1,2,3,4$<smiles>CC(=O)Oc1ccccc1C(=O)O</smiles>

Figure 2: Aspirin

\section{MATERIALS AND METHODS}

Instrument and equipment

1. RP-HPLC -Yonglin acme 9000

2. Sonicator- Vensor

3. UV Spectroscopy- Shimatzu 2080

\section{Materials}

1. Aspirin-Aspirin (AR grade) gifted sample from Scitech laboratory Musalgaon, MIDC, Sinner, Nashik .

2. Omeprazole-(AR grade) gifted sample from sci-tech laboratory Musalgaon MIDC, Sinner, Nashik.

3. Methanol-HPLC grade methanol purchase from Merck ltd, Mumbai.

4. Ortho phosparic acid water- $0.1 \mathrm{~mL}$ OPA in $200 \mathrm{~mL}$ water. $(0.05 \%)$

\section{Methods}

\section{Identification of Aspirin \& Omeprazole ${ }^{4}$}

Melting point was determined using digital melting point apparatus with one end open capillary method. The reference melting point of aspirin and omeprazole is $136^{\circ} \mathrm{C}$ and $156^{\circ} \mathrm{C}$ respectively.

\section{Determination of wavelength maxima ${ }^{5,6}$}

Both the standard solution was scanned between 400nm to $200 \mathrm{~nm}$. The overlain spectrum of both drugs was recorded. From the overlain spectrum, $297 \mathrm{~nm}(\lambda \max$ of omeprazole) and $222 \mathrm{~nm}$ ( $\lambda \max$ of Aspirin) were selected for estimation of drugs and the isobestic point was found to be at $231 \mathrm{~nm}$ and it is shown in fig 3

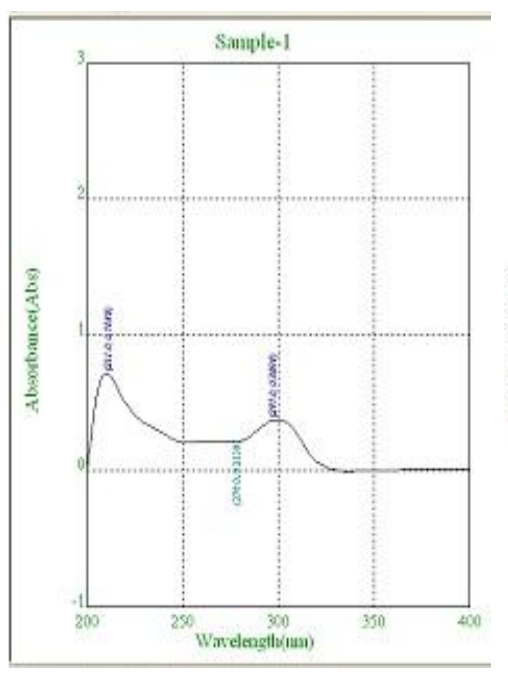

-UV of Aspirin
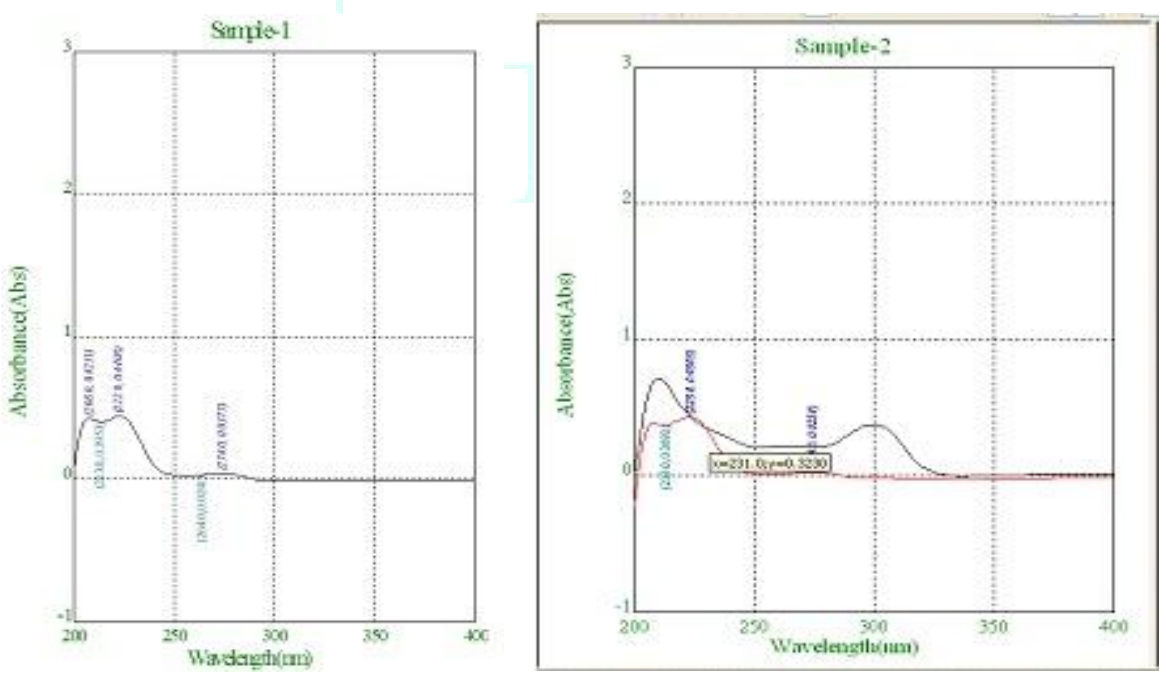

-UV of Omeprazole

Figure 3: Isobestic point of Omeprazole \& Aspirin

\begin{tabular}{|l|l|l|}
\hline Name of sample & Wavelength & Absorbance \\
\hline Omeprazole & $297 \mathrm{~nm}$ & 0.3698 \\
\hline Aspirin & $222 \mathrm{~nm}$ & 0.4408 \\
\hline $\begin{array}{l}\text { Isobestic Omeprazole } \\
\text { \& Aspirin }\end{array}$ & $231 \mathrm{~nm}$ & 0.3230 \\
\hline
\end{tabular}




\section{Selection of chromatographic mode}

Proper selection of the method depend upon the nature of the sample (ionic, ionisable and neutral, its molecular weight and solubility. Both the drugs are freely soluble in organic. Hence, reversed phase HPLC was selected for the initial separations because of its simplicity and suitability.

\section{Selection of Mobile phase}

Omeprazole and Aspirin are freely soluble in HPLC grade of methanol. Not freely soluble in orthophosphoric acid and used uitrasonication. Both drugs are soluble in methanol and orthophosphoric acid.

\begin{tabular}{|l|l|}
\hline Mobile Phase & $60+40($ Methanol+(0.05\%) OPA $)$ \\
\hline $\begin{array}{l}\text { Selection of } \\
\text { column }\end{array}$ & $4.6 \times 150 \mathrm{~mm}$ \\
\hline Wavelength & $231 \mathrm{~nm}$ \\
\hline Flow rate & $0.7 \mathrm{ml} / \mathrm{min}$ \\
\hline Column temp & Ambient \\
\hline Sample size & $20 \mu \mathrm{L}$ \\
\hline Retention time & 4.61 omeprazol, 8.35 aspirin \\
\hline Conclusion & $\begin{array}{l}\text { Satisfactory Resolution, } \\
\text { Theoretical Plate, Tailing Factor. }\end{array}$ \\
\hline
\end{tabular}

\section{RESULT AND DISCUSSION}

Orthophosparic acid water $-0.1 \mathrm{~mL}$ OPA in $200 \mathrm{~mL}$ water. $(0.05 \%)$

\section{Preparation of stock solution}

Accurately weighed of Omeprazole $10 \mathrm{mg}$ and $20 \mathrm{mg}$ Aspirin was taken in $10 \mathrm{~mL}$ volumetric flask and dissolved in $10 \mathrm{~mL}$ methanol. To get standard stock solution.1000 $\mu \mathrm{g} / \mathrm{mL}$ Omeprazole and $2000 \mu \mathrm{g} / \mathrm{mL}$ Aspirin. STOCK -I

\section{Preparation of mobile phase}

Pipette out $60 \mathrm{ml}$ of concentrated methanol and $40 \mathrm{ml}$ of $0.05 \%$ OPA make up the volume up to $100 \mathrm{ml}$ and Sonicate $5 \mathrm{~min}$.

1) Take $0.1 \mathrm{~mL}$ from the stock I and make up the volume with mobile Phase $10 \mathrm{~mL}=10 \mu \mathrm{g} / \mathrm{mL}$ Omeprazole and $20 \mu \mathrm{g} / \mathrm{mL}$ Aspirin.

2) Take $0.2 \mathrm{~mL}$ from the stock $I$ and make up the volume with mobile Phase $10 \mathrm{~mL}=20 \mu \mathrm{g} / \mathrm{mL}$ Omeprazole and $40 \mu \mathrm{g} / \mathrm{mL}$ Aspirin.

3) Take $0.3 \mathrm{~mL}$ from the stock $\mathrm{I}$ and make up the volume with mobile Phase $10 \mathrm{~mL}=30 \mu \mathrm{g} / \mathrm{mL}$ Omeprazole and $60 \mathrm{gm} / \mathrm{mL}$ Aspirin.

4) Take $0.4 \mathrm{~mL}$ from the stock $\mathrm{I}$ and make up the volume with mobile Phase $10 \mathrm{~mL}=40 \mu \mathrm{g} / \mathrm{mL}$ Omeprazole and $80 \mu \mathrm{g} / \mathrm{mL}$ Aspirin.

5) Take $0.5 \mathrm{~mL}$ from the stock $\mathrm{I}$ and make up the volume with mobile Phase $10 \mathrm{~mL}=50 \mu \mathrm{g} / \mathrm{mL}$ Omeprazole and $100 \mu \mathrm{g} / \mathrm{mL}$ Aspirin.

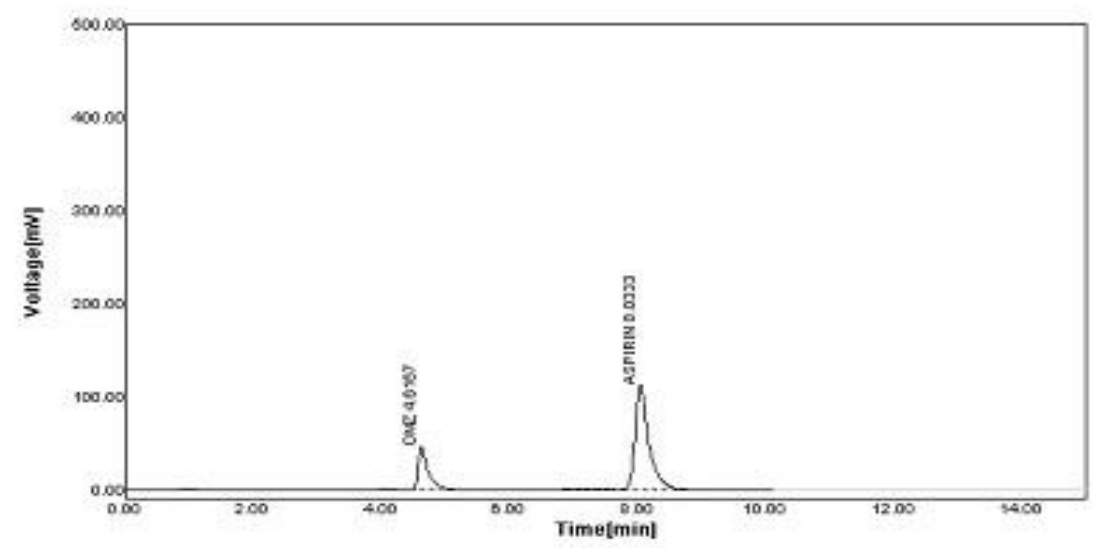

Figure 4: Chromatogram of Ome \& Asp

Table 1: Final chromatographic conditions

\begin{tabular}{|l|l|l|l|l|}
\hline $\begin{array}{l}\text { Peak } \\
\text { Name }\end{array}$ & $\begin{array}{l}\text { Retentio } \\
\text { n time }\end{array}$ & Area & $\begin{array}{l}\text { Plate } \\
\text { count }\end{array}$ & T F \\
\hline Ome & 4.6167 & 507.77 & 5060.1 & 1.1297 \\
\hline Asp & 8.0333 & 1753.2 & 9367.1 & 1.3266 \\
\hline
\end{tabular}

\section{Tab solution Preparation:}

\section{Brand Name: Yosprala}

Weigh and finely powder 20 tablets. Accurately weigh and transfer a quantity of powder sample equivalent to $10 \mathrm{mg}$ of Omeprazole and $20 \mathrm{mg}$ of Aspirin into a $10 \mathrm{ml}$ clean dry volumetric flask, add $10 \mathrm{ml}$ methanol and sonicate to dissolve it completely and make volume up to the mark with the diluents $(1000 \mu \mathrm{g} / \mathrm{mL}$ Ome and $2000 \mu \mathrm{g} / \mathrm{mL}$. From these solutions $0.1 \mathrm{ml}$ was pipette out and transferred into $10 \mathrm{ml}$ volumetric flask and makeup the volume up to the mark with methanol \& Orthophosphoric acid $(10 \mu \mathrm{g} / \mathrm{mL}$ Omeprazole and 20 $\mu \mathrm{g} / \mathrm{mL}$ Aspirin) and measured the absorbance at $231 \mathrm{~nm}$. The $\%$ purity of the drug was calculated by comparing the absorbance of test solution with standard.

Tab Assay ${ }^{7,8}$

$0.4 \mathrm{ml}$ from tab stock and make up $10 \mathrm{ml}$ with mobile phase and produced $40 \mu \mathrm{g} / \mathrm{mL}$ Ome $+80 \mu \mathrm{g} / \mathrm{mL}$ Asp for assay 


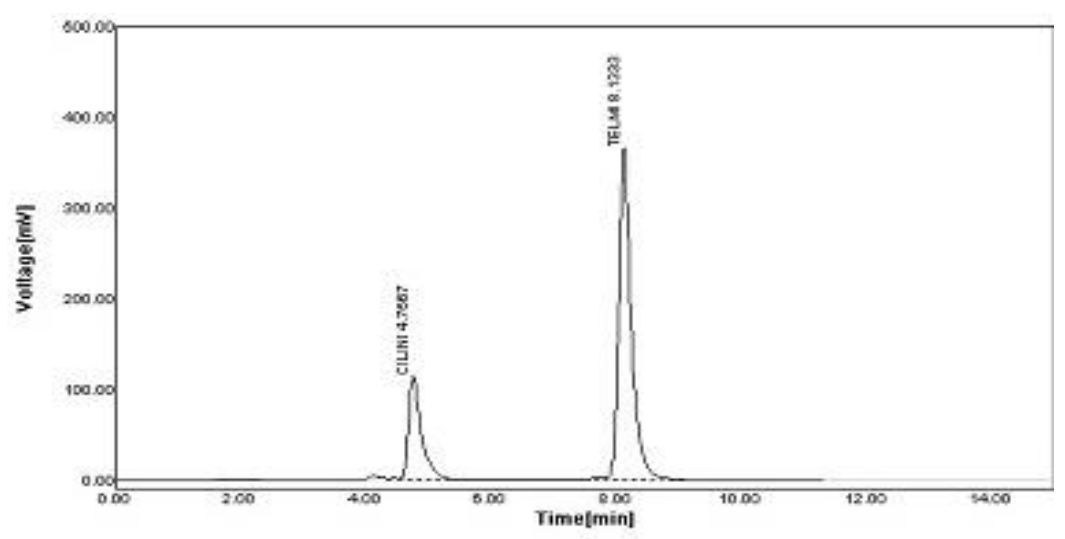

Figure 5: Chromatogram for Assay

Table 2: Assay

\begin{tabular}{|l|l|l|l|l|}
\hline Name & RT(min) & TP & TF & Area \\
\hline Ome & 4.7667 & 3827.0 & 1.33 & 1265.54 \\
\hline Asp & 8.1333 & 9876.3 & 1.37 & 5033.44 \\
\hline
\end{tabular}

\section{Validation Parameter $9,10,11,12$}

Linearity:-The con. of ome and asp solution take in different concentration respect.10-50ug/mL, 20$100 \mathrm{ug} / \mathrm{mL}$. At selected wavelength $231 \mathrm{~nm}$.

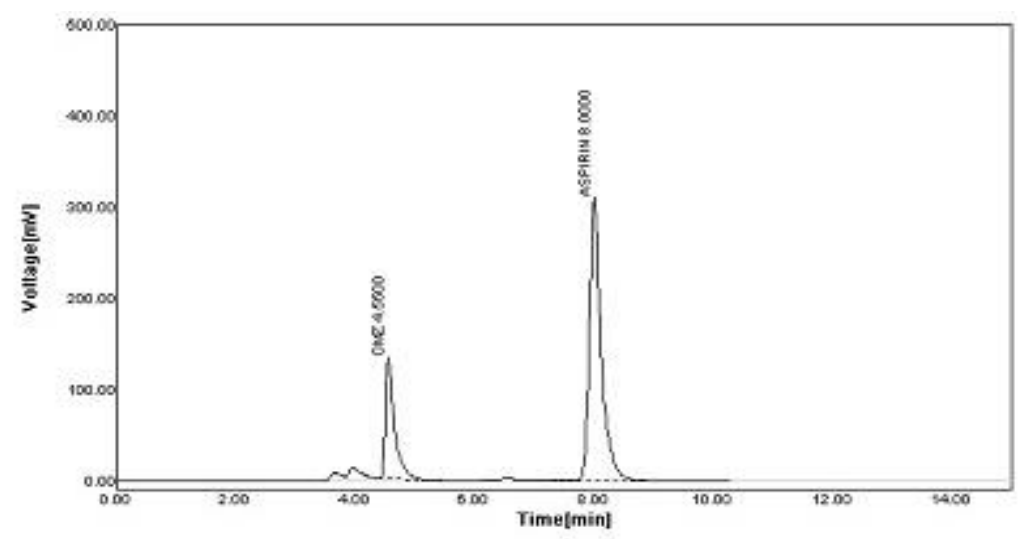

Figure 6: Linearity $50 \mu \mathrm{g} / \mathrm{mL}$ Ome \& $100 \mu \mathrm{g} / \mathrm{mL}$

\begin{tabular}{|l|l|l|l|l|}
\hline $\begin{array}{l}\text { Peak } \\
\text { Name }\end{array}$ & $\begin{array}{l}\text { Retention } \\
\text { time }\end{array}$ & Area & $\begin{array}{l}\text { Plate } \\
\text { count }\end{array}$ & T F \\
\hline Ome & 4.6000 & 1230.7 & 5503.1 & 1.1472 \\
\hline Asp & 8.0167 & 5042.1 & 9537.0 & 1.1699 \\
\hline
\end{tabular}

true value. The three triplicates of stock solution of Omeprazole and Aspirin equivalent to 10ppm, 20ppm, $30 \mathrm{ppm}$ and $20 \mathrm{ppm}, 40 \mathrm{ppm}$, 60ppm respectively were preparing by using standard solution. From stock solution aliquots of Ome and Aspirin $0.1 \mathrm{ml}, 0.2 \mathrm{ml}$, $0.3 \mathrm{ml}$ were taken and diluted to $10 \mathrm{ml}$ mobile phase with diluted such that the final concentration of Ome-10, 20,

Accuracy: The accuracy of an analytical method is the $30 \mu \mathrm{g} / \mathrm{mL}$ and Aspirin-20, 40, $60 \mu \mathrm{g} / \mathrm{mL}$. closeness of test results obtained by that method to the

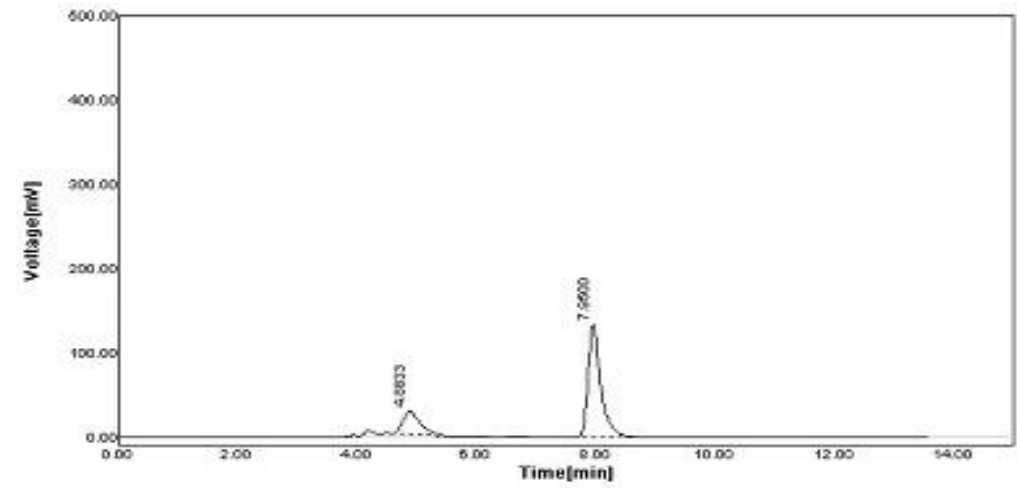

Figure 7: Chromatogram of accuracy Omeprazole 30 $\mu \mathrm{g} / \mathrm{mL}$ Aspirin $60 \mu \mathrm{g} / \mathrm{mL}$. 
Table 3: Accuracy of Omeprazole

\begin{tabular}{|l|l|l|l|}
\hline \multirow{2}{*}{$\begin{array}{l}\text { Conc. } \\
(\boldsymbol{\mu g} / \mathbf{m l})\end{array}$} & $\begin{array}{l}|l| \\
\text { Standard Deviation }\end{array}$ & \%RSD \\
\cline { 2 - 4 } & Mean & SD & \%RSD \\
\hline 10 & 288.91 & 2.63 & 0.91 \\
\hline 20 & 525.86 & 7.71 & 1.47 \\
\hline 30 & 778.18 & 3.34 & 0.43 \\
\hline
\end{tabular}

Table 4: Accuracy of Aspirin

\begin{tabular}{|c|l|l|l|}
\hline \multirow{2}{*}{$\begin{array}{l}\text { Conc. } \\
(\boldsymbol{\mu g} / \mathbf{m l})\end{array}$} & \multicolumn{2}{|l|}{ Standard Deviation } & \%RSD \\
\cline { 2 - 4 } & $\begin{array}{l}\text { Area } \\
\text { Mean }\end{array}$ & SD & RSD \\
\hline 20 & 706.42 & 5.03 & 0.71 \\
\hline 40 & 1741.04 & 7.25 & 0.99 \\
\hline 60 & 2863.04 & 3.78 & 0.13 \\
\hline
\end{tabular}

Precision:-The precision intraday and inter day Precision system result showed good reproducibility. Intraday precision study was carried out by preparing drug solution from stock solution, aliquots of Omeprazole and Aspirin 0.2, 0.3, $0.4 \mathrm{ml}$ were taken an diluted to $10 \mathrm{ml}$ with diluents such that the final concentration of Ome-20, 30, $40 \mu \mathrm{gm} / \mathrm{mL}$ and Asp-40, $60,80 \mu \mathrm{g} / \mathrm{mL}$ and analyzed. The same procedure was followed for second day also to determine inter-day precision.

Table 5: Intra-day precision

\begin{tabular}{|l|l|l|l|l|}
\hline $\begin{array}{l}\text { Conc } \\
\boldsymbol{\mu g} / \mathbf{m L}\end{array}$ & $\begin{array}{l}\text { Area } \\
\text { Mean }\end{array}$ & SD & $\begin{array}{l}\text { \%Amt } \\
\text { Found }\end{array}$ & $\begin{array}{l}\text { \% } \\
\text { RSD }\end{array}$ \\
\hline OME & & & & \\
\hline 20 & 530.32 & 6.74 & 100.42 & 1.27 \\
\hline 30 & 748.75 & 6.60 & 97.98 & 0.88 \\
\hline 40 & 996.01 & 5.40 & 99.84 & 0.54 \\
\hline ASP & & & & \\
\hline 40 & 1765.1 & 10.9 & 99.87 & 0.58 \\
\hline 60 & 2880.9 & 6.19 & 100.95 & 0.22 \\
\hline 80 & 3913.4 & 1.44 & 98.58 & 0.21 \\
\hline
\end{tabular}

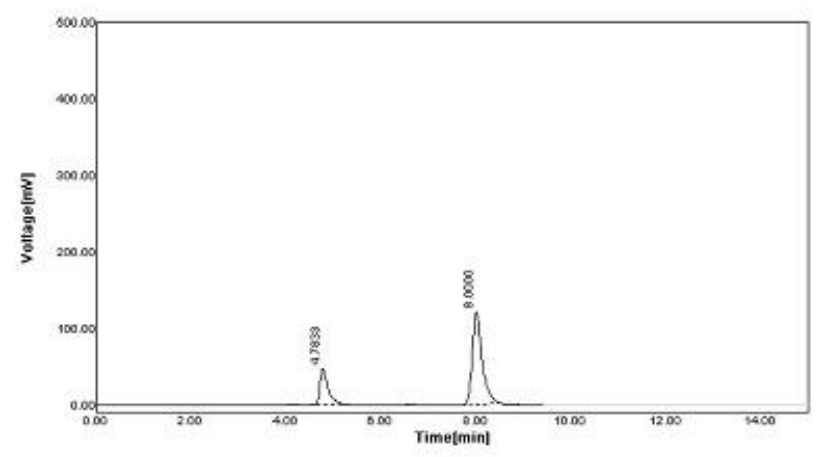

Figure 8: Precision-20ug/ml and 40ug/ml Intra-day
Table 6: Inter day precision

\begin{tabular}{|l|l|l|l|l|}
\hline $\begin{array}{l}\text { Conc. } \\
\text { ug/ml }\end{array}$ & $\begin{array}{l}\text { Area } \\
\text { Mean }\end{array}$ & SD & $\begin{array}{l}\text { \%Amt } \\
\text { Found }\end{array}$ & $\begin{array}{l}\text { \% } \\
\text { RSD }\end{array}$ \\
\hline OME & & & & \\
\hline 20 & 530.32 & 6.74 & 100.42 & 1.27 \\
\hline 30 & 763.32 & 4.88 & 100.15 & 1.57 \\
\hline 40 & 996.01 & 5.40 & 99.84 & 0.54 \\
\hline ASP & & & & \\
\hline 40 & 1765.5 & 10.1 & 99.87 & 0.58 \\
\hline 60 & 2880.9 & 6.19 & 100.95 & 0.22 \\
\hline 80 & 3913.4 & 1.44 & 99.58 & 0.04 \\
\hline
\end{tabular}

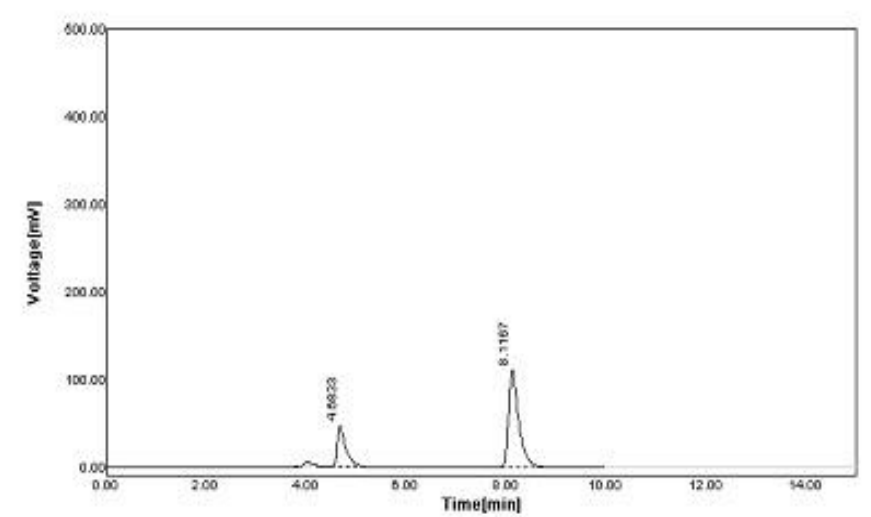

Figure 9: Precision-20ug/mL and 40ug/ml interday

$$
\% \text { Recovery }{ }^{13,14}
$$

The recovery of an analytical method is determined by applying the method to analyzed samples to which known amounts of analyte have been added. The Recovery is calculated from the test results as the percentage of analyte recovered by the assay. Three replicate injections, each of three different test concentrations in the range of $80 \%, 100 \%$ and $120 \%$ of labeled claim of tablet under study yielded the result within 98 to $102 \%$ of true concentration of each drug. The results indicated that the method is accurate.

Table 7: Statistical Validation of Recovery Studies Ome and Asp

\begin{tabular}{|c|c|c|c|c|}
\hline $\begin{array}{c}\text { Level of } \\
\text { Recovery } \\
(\%)\end{array}$ & Drug & $\begin{array}{c}\text { Mean \% } \\
\text { Recovery }\end{array}$ & $\begin{array}{c}\text { Standard } \\
\text { Deviation }\end{array}$ & $\begin{array}{c}\text { \% } \\
\text { RSD }\end{array}$ \\
\hline \multirow{2}{*}{$80 \%$} & Ome & 98.20 & 1.70 & 1.73 \\
\cline { 2 - 5 } & Asp & 99.10 & 0.75 & 0.64 \\
\hline \multirow{2}{*}{$100 \%$} & Ome & 101.16 & 1.78 & 0.44 \\
\cline { 2 - 5 } & Asp & 100.75 & 1.51 & 0.27 \\
\hline \multirow{2}{*}{$120 \%$} & Ome & 101.58 & 1.07 & 0.37 \\
\cline { 2 - 5 } & Asp & 99.23 & 0.41 & 0.11 \\
\hline
\end{tabular}




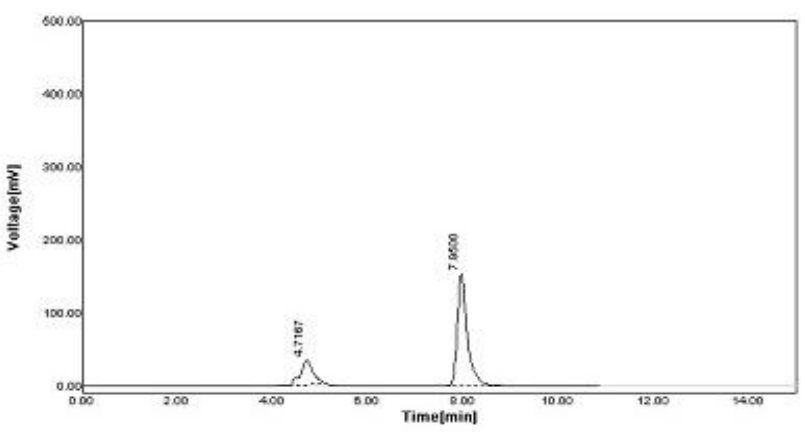

Figure 10: Recovery $120 \%$

Robustness ${ }^{16,17}$

The robustness of an analytical method is a measure of its capacity to remain unaffected by small but deliberate variations in method parameters and provides an indication of its reliability during normal usage. To verify the robustness of the method, the analysis was done under variables flow rate, mobile phase ratio and wavelength.

\section{System suitability parameter}

The system was evaluated by analyzing repeatability, retention time, tailing factor and theoretical plats of the column.

Table 8: Robustness study of Ome \& Asp

\begin{tabular}{|l|l|l|l|}
\hline $\begin{array}{l}\text { Parameter } \\
\text { change }\end{array}$ & $\begin{array}{l}\text { Conc. } \\
\text { ug/ml }\end{array}$ & $\begin{array}{l}\text { Amt. } \\
\text { Mean } \pm \text { SD }\end{array}$ & \%RSD \\
\hline $\begin{array}{l}\text { Flow rate } \\
0.6 \mathrm{ml}\end{array}$ & 32 & $1217.7 \pm 5.69$ & 0.88 \\
\hline $0.8 \mathrm{ml}$ & 32 & $1812.21 \pm 4.68$ & 0.26 \\
\hline $\begin{array}{l}69 \mathrm{ml}+31 \mathrm{ml} \\
\text { Me+OPA }\end{array}$ & 32 & $2099.53 \pm 24.9$ & 1.19 \\
\hline $\begin{array}{l}59 \mathrm{ml}+41 \mathrm{ml} \\
\text { Me+OPA }\end{array}$ & 32 & $1320.56 \pm 7.42$ & 0.56 \\
\hline $230 \mathrm{~nm}$ & 32 & $2099.53 \pm 5.69$ & 0.47 \\
\hline $232 \mathrm{~m}$ & 32 & $1855.70 \pm 32.8$ & 1.77 \\
\hline
\end{tabular}

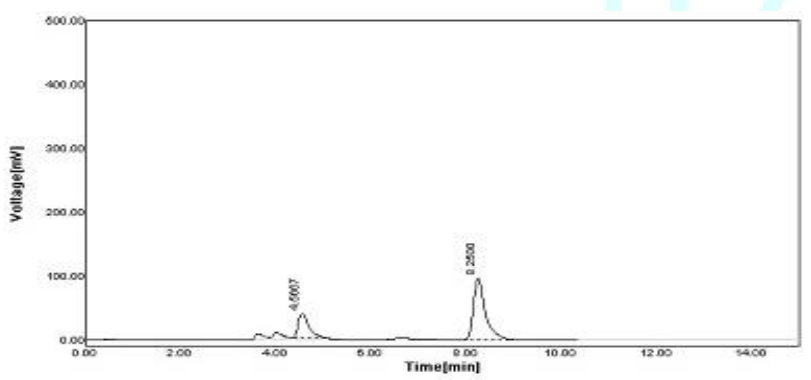

Figure 11: Change in wavelength $230 \mathrm{~nm}$.

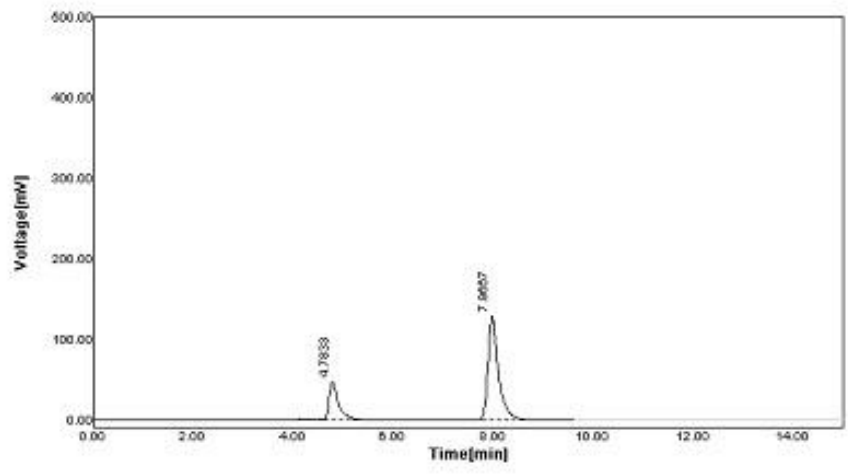

Figure 12: Change in wavelength $232 \mathrm{~nm}$.

\section{Limit of Detection (LOD)}

The LOD is the lowest limit that can be detected. Based on the S.D. of the response and the slope. The limit of detection (LOD) may be expressed as:

$$
\text { LOD = 3.3 (SD)/S }
$$

Where, $\mathrm{SD}=\mathrm{Standard}$ deviation of the $\mathrm{Y}$ intercept $S=$ Slope

$\mathrm{LOD}=3.3 \times 4.65 / 23.46=\mathbf{0 . 5 9 4 6}(\mu \mathrm{g} / \mathrm{ml})($ Omeprazole $)$ LOD $=3.3 \times 8.81 / 54.08=\mathbf{0 . 5 3 7 5}(\mu \mathrm{g} / \mathrm{ml})($ Aspirin $)$

The LOD of Omeprazole and Aspirin was found to be $\mathbf{0 . 5 9 4 6}(\mu \mathrm{g} / \mathrm{ml})$ and $\mathbf{0 . 5 3 7 5}(\mu \mathrm{g} / \mathrm{ml})$ respectively.

\section{Limit of Quantitation}

The LOQ is the lowest concentration that can be quantitatively measured. Based on the S.D. deviation of the response and the slope.

The quantitation limit (LOQ) may be expressed as

$$
\text { LOQ = } 10 \text { (SD)/S }
$$

Where, $\mathrm{SD}=$ standard deviation of $\mathrm{Y}$ intercept

$\mathrm{S}=$ Slope

LOQ $=10 \times 4.65 / 23.46=\mathbf{1 . 9 8 2 0} \quad(\mu \mathrm{g} / \mathrm{ml}$ (Omeprazole)

$\mathrm{LOQ}=10 \times 8.81 / 54.08=\mathbf{1 . 6 2 9 0} \quad(\mu \mathrm{g} / \mathrm{ml}$ (Aspirin)

The LOQ of Omeprazole and Aspirin was found to be $\mathbf{1 . 9 8 2 0}(\mu \mathrm{g} / \mathrm{mL})$ and $\mathbf{1 . 6 2 9 0}(\mu \mathrm{g} / \mathrm{mL})$ respectively.

\begin{tabular}{|c|c|c|c|c|}
\hline \multicolumn{2}{|c|}{ Parameter (Unit) } & Ome & Asp & Accep. Criteria \\
\hline \multicolumn{2}{|c|}{ Linearity range $(\mu \mathrm{g} / \mathrm{ml})$} & $10-50$ & $20-100$ & $\begin{array}{ll}---- \\
\end{array}$ \\
\hline \multicolumn{2}{|c|}{ Correlation Coefficient } & 0.9995 & 0.9987 & 0.999 \\
\hline \multicolumn{2}{|c|}{ \% Recovery } & $98.20-101.58 \%$ & $99.10-99.23 \%$ & $98 \%-102 \%$ \\
\hline \multirow{2}{*}{$\begin{array}{c}\text { Precision } \\
\% \text { RSD }\end{array}$} & Intraday & $1.27 \%$ & $0.58 \%$ & \multirow[b]{2}{*}{$\%$ RSD NMT 2} \\
\hline & Inter day & $1.27 \%$ & $0.58 \%$ & \\
\hline \multicolumn{2}{|c|}{ Robustness } & Robust & Robust & Robust \\
\hline \multicolumn{2}{|c|}{ LOD } & $0.5946 \mu \mathrm{g} / \mathrm{ml}$ & $0.5375 \mu \mathrm{g} / \mathrm{ml}$ & NMT 2 \\
\hline \multicolumn{2}{|c|}{ LOQ } & $1.9820 \mu \mathrm{g} / \mathrm{ml}$ & $1.6290 \mu \mathrm{g} / \mathrm{ml}$ & NMT 2 \\
\hline
\end{tabular}

Summary of validation parameter 


\section{CONCLUSION}

RP-HPLC method has been developed for the simultaneous estimation of Omeprazole and Aspirin. These methods have good resolution both the drugs good and short analysis time. Literature survey revealed that several methods have been reported for determination of Omeprazole and Aspirin individually or in combination with other drugs in pharmaceutical

\section{REFERENCES}

1. Kalshetti MS, Kasabe S, Chauhan N, Dhanshri S, Kale B, International Journal of Research in Pharmacy and Pharmaceutical Sciences, Development and validation of RPHPLC method for simultaneous estimation of aspirin and omeprazole in dosage, 2017; 2(4):45-51.

2. www.yosprala.com.

3. www.drugbank.com/Aspirin.

4. Indian Pharmacopoeia, Government of India, Ministry of Health and Family Welfare, Published by the controller of publication, Delhi 1, 1996, 469.

5. Kranthi KK, Supriya D, Divya D, Rani D, Neelima Munni G, International journal of pharmaceutical Investigations and Research Analytical method development and validation for the estimation of aspirin and omeprazole using RP-HPLC method, ICJPIR, 2017; 4(1).

6. Saravanan V., Revathi R., Meera N. Method development and validation for the simultaneous estimation of lycopene and ubidecarenone by RP-HPLC in combined pharmaceutical dosage form. Journal of Drug Delivery and $\begin{array}{ll}\text { Therapeutics, 2016; 6(5):46-51. } & \text {. }\end{array}$ https://doi.org/10.22270/jddt.v6i5.1295

7. Practical HPLC methods developments ACS short course attendees' onl. Available from:www.bioanalytical.com/NWL/pdfs/acs.pd f. Accessed on 2006 Jan.

8. Notes for guidance on guidance on validation of analytical procedures: Methodology (CPMP/ICH/281/95).

9. Ravisankar P, Rajyalakshmi G, Devadasu C, Devala Rao G, Instant tips for right and effective approach to solve HPLC trouble shooting, Journal of chemical and pharmaceutical sciences. 2014; 7(3):259-274.

10. Javali B, Sravanthi B, Rao BM, Gopi K, Vamsi K, Rao AK, Prasanthi T, Global journal of Pharmacy \& pharmaceutical Science, Development and Validation of UV Spectrophotom- dosage forms. The developed method was validated. It was found to be simple, precise, accurate and robust. The proposed method can be used for routine analysis of omeprazole and Aspirin in combined dosage form.

\section{ACKNOWLEDGMENT}

Authors are thankful to sci-tech pharma, sinner, india. Provide gift sample of Omeprazole and Aspirin.

etric Method for Simultaneous Estimation of Omeprazole and Domperidone in Capsule Dosage forms. 2017; 1(2):1-4

11. Gousuddin M, Sengupta P, Tripathi V, Das A, Malaysian Journal of Analytical Sciences, Malaysian Journal of Analytical Sciences, 2016; 20(2):247-257.

12. Singh D, Yadav H, Hinge M, Patel A, J Pharm Sci Bioscientific Res. Development and Validation of Analytical Methods for Simultaneous Estimation of Rosuvastatin, Clopidogrel and Aspirin in Pharmaceutical Dosage Form. 2016; 20(2):247-257.

13. Foram J. Chodvadiya, Thula K, Maheshwari D, International Journal of Recent Scientific Research, Simultaneous Estimation of Aspirin and Lansoprazol by RP-HPLC method, 2016; 6(4):3385-3390.

14. Kayesh P, ARahman, Sultan M, et al. Development and Validation of a RP-HPLC Method for the Quantification of Omeprazole in Pharmaceutical Dosage Form. J. Sci. Res. 2013; 5(2):335-3425.

15. Bhowmick M., Bhowmick P., Sengodan T., Thangavel S. Development and validation of bioanalytical RP HPLC method for the estimation of metoprolol tartrate in rabbit plasma after transdermal and oral administration: application in pharmacokinetic studies. Journal of Drug Delivery and Therapeutics, 2015; https://doi.org/10.22270/jddt.v5i4.1118

16. Kumar S, Jamadar L, Bhat K, Musmade P. A Ssantharaju, Udupa N, Analytical method development and validation for Aspirin, J. International Journal of ChemTech Research, 2010; 2(1):389-399.

17. Khristi A, Mardia R, Suhagia B, UV Spectrophotometric method development and validation of first derivative method for simultaneous estimation of sildenafil citrate and aspirin in bulk and tablet dosage form, J. Indo American Journal of Pharmaceutical Research, 2015; 2837-2843. 